\title{
The influence of postnatal nutrition on reproductive tract and endometrial gland development in dairy calves
}

\author{
Meghan L. Wilson, ${ }^{*}$ Sarah R. McCoski, ${ }^{*}$ Adam J. Geiger,† R. Michael Akers,† Sally E. Johnson, ${ }^{*}$ \\ and Alan D. Ealy*1 \\ *Department of Animal and Poultry Sciences, and \\ †Department of Dairy Sciences, Virginia Tech, Blacksburg 24061
}

\begin{abstract}
Uterine gland development occurs after birth in cattle and other mammals. The timeline of gland development has been described in various species, but little is known about how postnatal diet influences uterine gland development. This is especially concerning in dairy heifers, where a variety of milk replacer and whole milk nutrition options exist. Little work also exists in cattle to describe how early exposure to steroids influences reproductive tract and uterine gland development. The objective of this work was to determine the effects of early postnatal plane of nutrition and estrogen supplementation on uterine gland development in calves. In both studies, Holstein heifer calves were assigned to restricted milk replacer (R-MR) or enhanced milk replacer (EH-MR) diets. In study 1 , calves (R-MR, $\mathrm{n}=6$; EH-MR, $\mathrm{n}=5$ ) were euthanized at 8 wk. In study 2 , calves were weaned at 8 wk and administered estradiol (R-MR, $\mathrm{n}=6$; EH-MR, $\mathrm{n}=$ 6) or placebo (R-MR, $\mathrm{n}=6$; EH-MR, $\mathrm{n}=5$ ) for an additional $14 \mathrm{~d}$ before euthanasia. Average daily gain and final body weight was greater in both studies in heifers fed the enhanced diet. At 8 wk, EH-MR calves had a greater number of glands and a smaller average gland size, but total gland area was not different from the R-MR group. At $10 \mathrm{wk}$, uterine gland number and size were not affected by diet or estrogen. Expression profiles of several paracrine mediators of gland development were examined. Increases in transcript abundance for IGF1 and IGFBP3 and a decrease in abundance of $W N T 7 A$ were detected in calves fed the enhanced diet at 8 wk of age. Plane of nutrition did not affect transcript profiles at 10 wk of age, but estradiol supplementation decreased MET and WNT7A transcript abundance. To conclude, heifer calves on a restricted diet exhibited a uterine morphology and transcript profile suggestive
\end{abstract}

Received August 17, 2016.

Accepted December 19, 2016.

${ }^{1}$ Corresponding author: ealy@vt.edu of delayed uterine gland development. These changes appear to be corrected by wk 10 of life. Also, this work provides evidence supporting the contention that early estradiol exposure has detrimental effects on uterine gene expression.

Key words: uterus, reproductive tract, growth factors, milk replacers

\section{INTRODUCTION}

Mammalian uteri are devoid of endometrial glands at birth. The postnatal development of glands, or adenogenesis, begins immediately after birth and is normally complete by 8 wk of age in gilts and ewe lambs (Bartol et al., 1988b, 1999). The timeline for uterine gland development in cattle has not been described. This process involves a coordinated series of events wherein luminal epithelium differentiate into glandular epithelium located in the glandular buds present throughout regions of the uterus that do not contain caruncles. These invaginations form tubules that eventually coil and branch throughout the stroma to form an extensive network of uterine glands (Gray et al., 2001a).

The primary function of uterine glands is to produce and secrete epithelial products and selectively transport serum compounds into the uterine luminal fluid (Spencer, 2014). This mix of ions, AA, carbohydrates, proteins, lipids, and biologically active factors (e.g., growth factors) are essential for the continuation of early pregnancy. Ewes lacking uterine glands because of neonatal steroid hormone exposure undergo normal estrous cyclicity and produce viable embryos, but the embryos die around the time of maternal recognition of pregnancy (Gray et al., 2001b).

Avoiding steroid-containing implants or legumes that contain large quantities of phytoestrogens is recommended for cattle and other ruminants before puberty to prevent diminished reproductive potential in adulthood (Adams, 1995a; Becker et al., 2011). Heifers implanted with Compudose estradiol implant (Elanco Animal Health, Greenfield, IN), a nonsteroidal 
estrogen agonist, have increased incidence of ovarian cysts (Deutscher et al., 1986). Uterine gland development also is compromised with early postnatal steroid exposure. The most severe reductions in uterine gland number and size occur in sheep, pigs, and cattle when estradiol or progesterone exposure begins at birth. Females display a permanent reduction or a total absence of uterine glands that persists throughout life (Bartol et al., 1988a, 1995; Spencer et al., 1993; Gray et al., 2001a). Endometrial gland density and uterine fluid content also is reduced by estrogen administration in 3- and 6-wk-old heifers (Bartol et al., 1995).

It is unclear how early postnatal nutrition affects adenogenesis. This is especially concerning in dairy heifers, where a variety of milk replacer and whole milk nutrition options exist. A commonly used dairy calf milk replacer ration includes low amounts of protein and fat to promote early starter grain consumption, which hastens rumen development and, ultimately, reduces the overall feed costs (Brown et al., 2005; Hill et al., 2008). This scheme also eases the transition from a milk- to a grain-based diet at weaning. Other milk replacer rations contain greater protein and fat content, so they more closely approximate the composition and caloric density of normal cow milk. The high-protein, highfat ration increases BW and ADG in the first several months of life (Hill et al., 2008; Daniels et al., 2009). Reductions in the age at puberty and first calving and increases in first-lactation milk production are reported in calves consuming high-protein, high-fat milk replacer rations when compared with calves consuming diets containing lower protein and fat (Davis Rincker et al., 2011; Soberon and Van Amburgh, 2013).

The current work was undertaken to obtain a more complete understanding of how early postnatal nutrition and estrogen supplementation at weaning influences reproductive tract morphology and uterine gland development in dairy heifers. Our hypothesis was that changes in preweaning nutrition (i.e., during the first 8 wk of life) influences reproductive tract development and uterine gland formation and that estradiol supplementation at weaning adversely affects these processes.

\section{MATERIALS AND METHODS}

\section{Animal Handling and Experimental Design}

Animal experiments were completed in accordance with and with the approval of the Virginia Tech Institutional Animal Care and Use Committee (\#14045-DASC). Two studies were initially conceived to examine how postnatal plane of nutrition and early estradiol exposure affects mammary gland develop- ment. An initial publication of these findings has been completed (Geiger et al., 2016). The feeding scheme, time intervals, and use of heifer calves (expensive to use for terminal studies) provided the opportunity for companion studies examining the influences of early plane of nutrition and estradiol exposure on reproductive tract development.

The 2 studies used the same early postnatal feeding scheme. In both studies, Holstein heifer calves (Bos taurus taurus) were purchased from a commercial producer and maintained at the Virginia Tech Dairy Center (Blacksburg, VA). Calves were fed similarly for the first 5 to $8 \mathrm{~d}$ of life (Geiger et al., 2016). At $6 \pm 2$ d of age, calves were assigned randomly to restricted (R) or enhanced (EH) milk replacer (MR). The R diet $(20.9 \%$ CP, $19.8 \%$ fat, DM basis; Southern States Inc., Richmond, VA) was fed at $0.44 \mathrm{~kg}$ of MR powder/ animal per day. The EH diet $(28.9 \% \mathrm{CP}, 26.2 \%$ fat, DM basis; Land O'Lakes Animal Milk Products Co., Shoreview, MN) was fed at $1.08 \mathrm{~kg}$ of MR powder/animal per day. Both MR were reconstituted to $15 \%$ (wt/vol) water and fed in 2 equal portions at 0600 and $1700 \mathrm{~h}$ daily. At the beginning of wk 8, the amount of MR offered was reduced by half to prepare calves for weaning. Heifers were weaned at the end of wk 8. Calves were offered water ad libitum throughout the study. At the end of wk 4, calves were pair-fed starter grain to keep starter intakes similar between groups $(25.6 \% \mathrm{CP}, 4.0 \%$ fat, 19.8\% NDF, DM basis; Southern States Cooperative). This was achieved by offering R-fed calves the average amount of starter grain consumed by ad libitum, EH-fed calves on the preceding day. Milk replacer and feed refusals, weekly growth measurements (BW, hip and withers height, heart girth), and daily fecal and respiration scores are described elsewhere (Geiger et al., 2016). On only a few occasions did calves not consume their entire allotment of milk replacer, and these occasions usually occurred during the first week on their diet.

The 2 studies differed in the duration on diet. In the first study, $\mathrm{R}-(\mathrm{n}=6)$ and EH-fed $(\mathrm{n}=5)$ calves were euthanized at the end of wk 8 ( $56 \pm 2 \mathrm{~d}$ of age). In the second study, R- and EH-fed calves (R-MR, $\mathrm{n}=12$; EH-MR, $\mathrm{n}=11$ ) were weaned and then maintained exclusively on starter grain (pair-wise fed) until the end of wk 10. An estradiol implant (R-MR, $\mathrm{n}=6$; EH$\mathrm{MR}, \mathrm{n}=6)$ or a blank silicone implant $(\mathrm{R}-\mathrm{MR} \mathrm{n}=6$; EH-MR $\mathrm{n}=5$ ) was inserted into the ear of calves at the time of weaning, as described previously $(25.7 \mathrm{mg}$ of estradiol-17 $\beta$; Compudose Implant; Elanco Animal Health, Greenfield, IN; Lammers et al., 1999). Circulating estradiol concentrations were not determined, but, according to manufacturer specifications, calves were 
anticipated to contain approximately $120 \mathrm{pg} / \mathrm{mL}$ of circulating estradiol concentrations for approximately $36 \mathrm{~h}$ and then 70 to $80 \mathrm{pg} / \mathrm{mL}$ of estradiol thereafter. Calves were euthanized $14 \mathrm{~d}$ after implant or placebo insertion (70 $\pm 2 \mathrm{~d}$ of age).

\section{Reproductive Tract Measurements}

Calves were euthanized using a lethal dose of phenobarbital administered intravenously (Fatal-Plus, 10 $\mathrm{mg} / \mathrm{kg}$ of BW, Vortech Pharmaceuticals, Dearborn, MI). A mid-ventral incision was made and the reproductive tract was removed. The broad ligament and vagina were trimmed away and the remainder of the tract was rinsed with water, dried, and weighed. Thereafter, ovaries, oviducts (trimmed of connective tissue), cervix, and uterus were dissected and weighed. Visible follicles were counted on each ovary.

\section{Endometrial Gland Morphometrics}

Uterine samples $\left(0.3-0.7 \mathrm{~cm}^{3}\right)$ from the midpoint of each uterine horn were collected. Tissue was rinsed briefly in $0.01 M$ PBS (pH 7.4), fixed with $3.7 \%$ (wt/ vol) formaldehyde, and infiltrated with paraffin (HistoScientific Research Laboratories, Mt. Jackson, VA). Four sections $(5 \mu \mathrm{m})$ from each animal (2 sections for each uterine horn) were collected on glass slides, deparaffinized, rehydrated through a graded alcohol series, and stained with hematoxylin. The sections were further processed through a graded alcohol and xylene series and cover-slipped. Eight representative microscopic field images at 100-fold magnification were captured and digitized for each heifer using a Nikon Eclipse-Ti inverted microscope equipped with a chargecoupled camera (SPOT, Diagnostic Imaging, Sterling Heights, MI) and shutter control provided by NIS Elements software (Nikon Instruments Inc., Melville, NY). Examples of the uterine gland morphology are illustrated in Figure 1. Uterine glands containing fluid-filled lumens were readily detectable given the high contrast of the glandular epithelium (GE). This permitted quantification of gland numbers and size without using endometrial gland markers (e.g., FOXA2; Waters et al., 2014). Uterine glands not containing a lumen were not recorded. Only intercaruncular endometrium was analyzed (caruncular regions do not contain glands). Gland size was measured by tracing individual structures using NIS Elements software (Nikon Instruments Inc.). Percentage of cross sectional area containing glands was determined by dividing gland area with total cross sectional area. Total gland numbers were recorded for each image.

\section{Endometrial Transcript Profiling}

Multiple endometrial samples were collected from throughout each uterine horn and combined into pools (4-8 samples/pool) to ensure that pools contained samples from the entire endometrium, including both caruncular and intercaruncular regions (Ocón-Grove et al., 2008). Tissues were snap-frozen in liquid nitrogen. The RNA was extracted by homogenization and phase separation in TRIzol reagent (Thermo Fisher Scientific, Waltham, MA) and purified with the PureLink RNA Mini Kit (Thermo Fisher Scientific). Purity and quantity of RNA was determined using a NanoDrop 2000 Spectrophotometer (Thermo Fisher Scientific). Only samples containing an absorbance ratio at 260 and 280 $\mathrm{nm}>1.8$ were used.

Quantitative reverse-transcription (RT) PCR was completed as described previously (Yang et al., 2011) to examine how plane of nutrition and estradiol treatment influence transcript abundance for several putative mediators of adenogenesis. In brief, total RNA (10 $\mathrm{ng} /$ reaction) was treated with RNase-free DNase (New England Biolabs, Ipwich, M) and reverse transcribed (High Capacity cDNA Reverse Transcription Kit, Applied Biosystems, Austin, TX). Then PCR was completed using SYBR Green Master Mix reagent (Applied Biosystems) and specific primer pairs (Table 1) using an Eppendorf Real-Plex Master Cycler (Eppendorf North America, Hauppauge, NY). Primer pairs were validated for efficiency before use (range $=89-103 \%$; 60 to 300 bp amplification). Reactions were completed with 40 amplification cycles using 57 to $60^{\circ} \mathrm{C}$ annealing/synthesis (depending on the transcript) for $1 \mathrm{~min}$ and $95^{\circ} \mathrm{C}$ denaturation for $15 \mathrm{~s}$. Amplification of a single PCR product was verified for each PCR run by dissociation curve analysis. Non-reverse transcribed RNA samples were included as negative controls. Ribosomal protein L19 (RPL19) served as the internal reference control; $R P L 19$ was an appropriate reference control for the bovine endometrium in previous work (McCarthy et al., 2012), and RPL19 mRNA abundance did not differ based on diet or estrogen treatment in these studies (data not shown). The comparative threshold quantification cycle $\left(\mathbf{C}_{\mathbf{T}}\right)$ method was used to quantify mRNA abundance (Cooke et al., 2009). The average $\Delta \mathrm{C}_{\mathrm{T}}$ value for each sample was calculated $\left(\mathrm{C}_{\mathrm{T}}\right.$ transcript of interest $-\mathrm{C}_{\mathrm{T}}$ RPL19) and used to calculate the fold-change in relative abundance for each transcript.

\section{Statistical Analyses}

Data were analyzed by ANOVA using the general linear model (GLM) of the SAS (ver. 9.3, SAS Institute 
Inc., Cary, NC) for the effects of diet, estradiol treatment, replicate, and their interactions. Three batches of calves were acquired for the work (Geiger et al., 2016), but no statistically significant effects of batch were detected; thus, this term was not included in the final analysis. Covariates were included to normalize follicle numbers for ovarian weight and to adjust the uterine gland assessments based on total cross sectional

\section{R-MR}
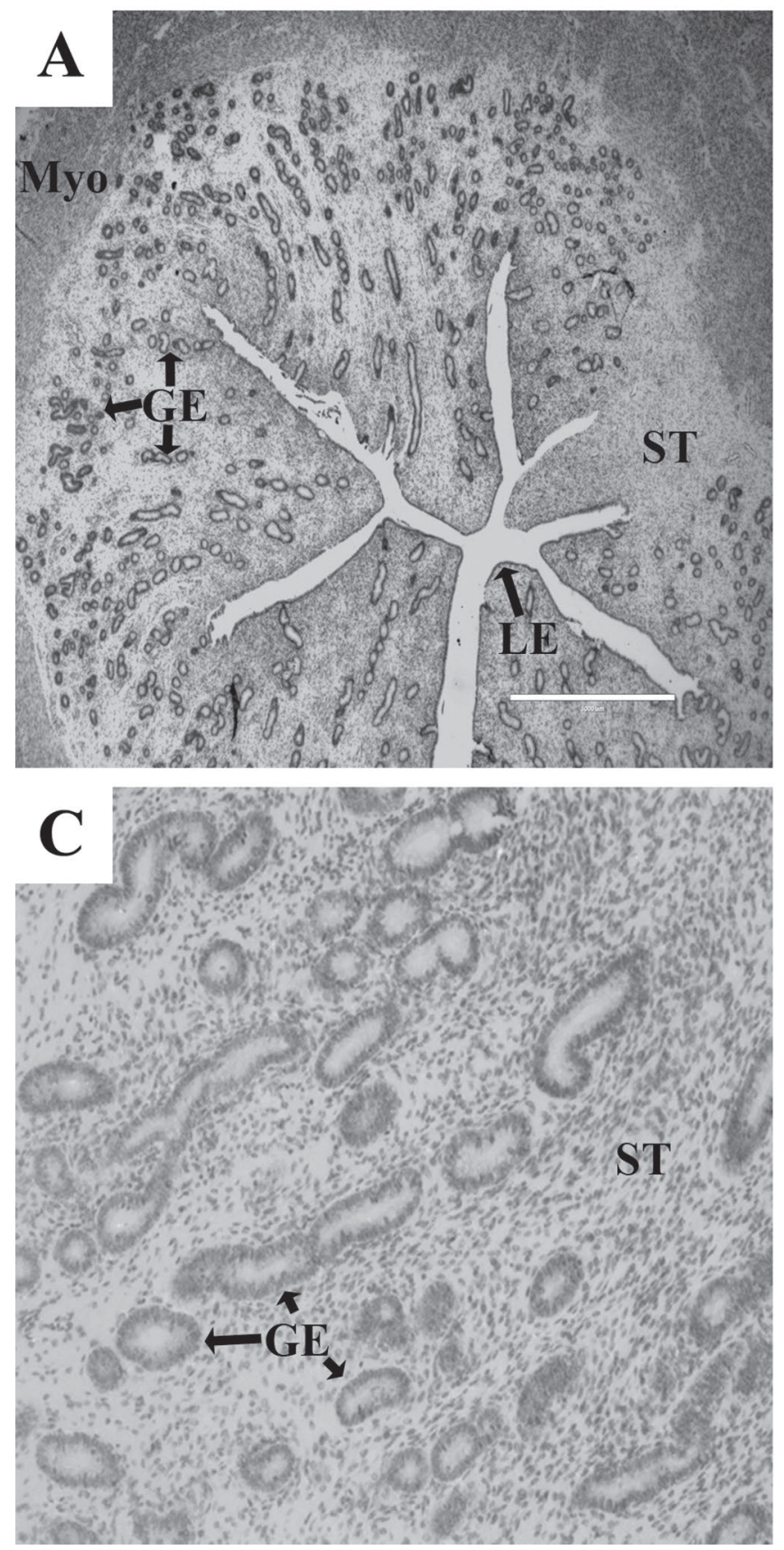

EH-MR
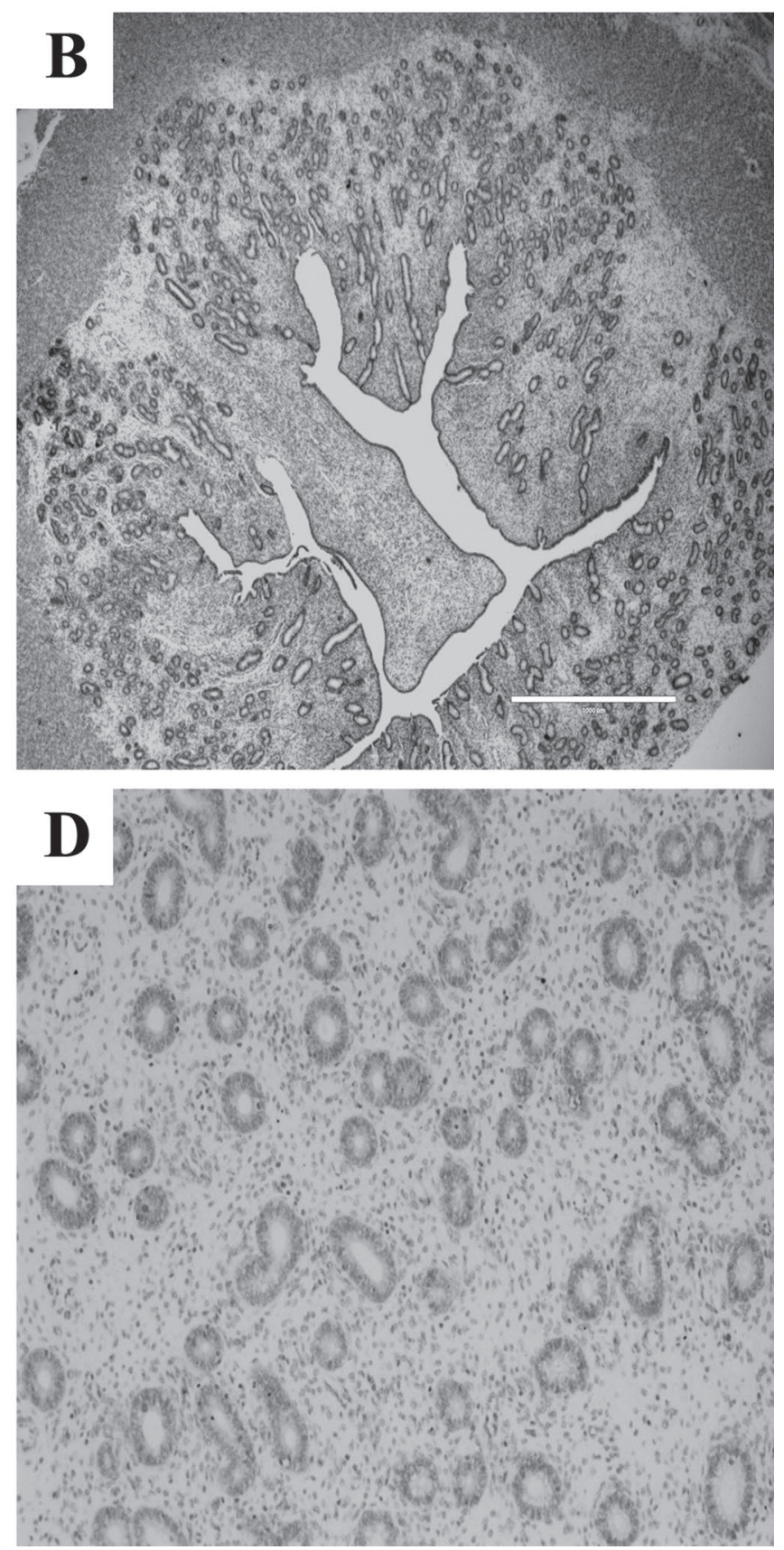

Figure 1. Representative uterine cross sections at $8 \mathrm{wk}$ of age for heifer calves fed either a restricted (R) or enhanced (EH) milk replacer (MR) diet. Endometrial cross sections were harvested and processed for hemotoxylin staining and image analysis. (A, B) Representative endometrial cross sections of the entire reproductive tract at 8 wk in heifers fed the $\mathrm{R}$ or $\mathrm{EH}$ diets $(10 \times$ magnification; bar $=1 \mathrm{~mm}$ scale). ( $\mathrm{C}$, D) Representative endometrial cross sections of glandular epithelium images used to quantify numbers and sizes of endometrial glands (200x magnification). Labels indicate luminal epithelium (LE), glandular epithelium (GE), stroma (ST), and myometrium (Myo). 
Table 1. Primer sequences

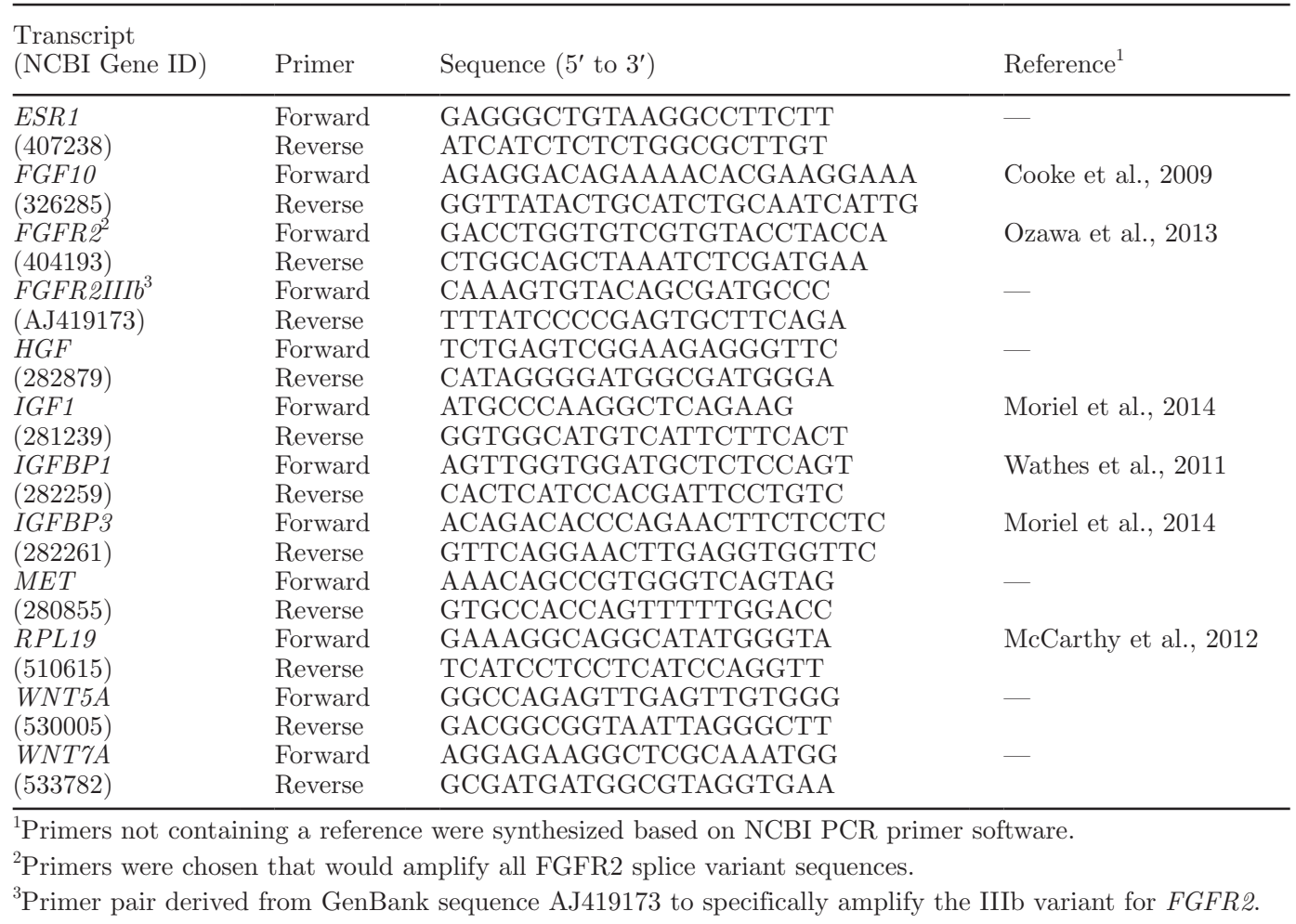

area. Fold-change quantitative RT-PCR data were log-transformed before analysis. When needed, individual means were compared by pair-wise comparisons (PDIFF analysis). Data presented as arithmetic means \pm SEM. Differences were considered significant at $P \leq$ 0.05 .

\section{RESULTS}

\section{Calf Performance on Diets and with Estrogen Treatment}

Calf feed intake, growth performance, and health observations are reported in a separate manuscript (Geiger et al., 2016). Both BW and ADG data are presented to illustrate growth rate differences based on diet and estrogen treatment. Beginning BW was not different between treatment groups in the first or second study (average $40.4 \pm 1.4$ and $38.9 \pm 1.8 \mathrm{~kg}$, respectively); however, EH-fed calves were heavier $(P<0.01)$ than R-fed calves after 8 (Table 2) and 10 wk (Table 3). Estradiol treatment did not affect BW at the end of wk 10 in $\mathrm{R}$-fed calves, but BW was greater $(P<0.05)$ in $\mathrm{EH}$-fed calves containing an estradiol implant than EH calves without estrogen (Table 3 ).

The ADG was greater $(P<0.01)$ for EH- than Rfed calves on diets between wk 1 and 8 in both the first (Figure 2A) and second (Figure 2B) study. In the second study, diet affected ADG at wk 9 and 10, with R-fed calves exhibiting greater $(P<0.01)$ ADG than EH-fed calves regardless of estradiol treatment $(0.88$ \pm 0.06 vs. $0.61 \pm 0.06 \mathrm{~kg} / \mathrm{d})$. Pair-wise comparisons

Table 2. Reproductive tract weights and follicle numbers of heifer calves fed either a restricted $(\mathrm{R})$ or enhanced $(\mathrm{EH})$ milk replacer $(\mathrm{MR})$ diet for $8 \mathrm{wk}( \pm$ SEM $)$

\begin{tabular}{lcc}
\hline Parameter $^{1}$ & $\begin{array}{c}\text { R-MR } \\
(\mathrm{n}=6)\end{array}$ & $\begin{array}{c}\text { EH-MR } \\
(\mathrm{n}=5)\end{array}$ \\
\hline Final BW $(\mathrm{kg})$ & $52.3 \pm 1.6^{\mathrm{a}}$ & $81.7 \pm 4.2^{\mathrm{b}}$ \\
Reproductive tract & $22.7 \pm 1.9^{\mathrm{a}}$ & $36.8 \pm 1.9^{\mathrm{b}}$ \\
$\mathrm{g}$ & $0.47 \pm 0.03^{\mathrm{a}}$ & $0.48 \pm 0.03^{\mathrm{a}}$ \\
$\mathrm{g} / \mathrm{kg}$ of BW & $17.8 \pm 1.8^{\mathrm{a}}$ & $25.6 \pm 1.0^{\mathrm{b}}$ \\
Uterus & $0.37 \pm 0.03^{\mathrm{a}}$ & $0.33 \pm 0.01^{\mathrm{a}}$ \\
$\mathrm{g}$ & & \\
g/kg of BW & $4.7 \pm 0.3^{\mathrm{a}}$ & $7.2 \pm 0.9^{\mathrm{b}}$ \\
Cervix & $(0.09 \pm 0.01)^{\mathrm{a}}$ & $(0.09 \pm 0.01)^{\mathrm{a}}$ \\
g & $2.1 \pm 0.5^{\mathrm{a}}$ & $3.0 \pm 0.6^{\mathrm{a}}$ \\
g/kg of BW & $0.05 \pm 0.01^{\mathrm{a}}$ & $0.04 \pm 0.01^{\mathrm{a}}$ \\
Ovaries & & \\
g & $30.7 \pm 10.0^{\mathrm{a}}$ & $31.0 \pm 12.1^{\mathrm{a}}$ \\
g/kg of BW & $12.0 \pm 2.8^{\mathrm{a}}$ & $9.1 \pm 1.9^{\mathrm{a}}$ \\
Follicle numbers & Total & \\
Number/g of tissue &
\end{tabular}

${ }^{\mathrm{a}, \mathrm{b}}$ Different superscripts within row denote differences $(P<0.05)$.

${ }^{1}$ Weight data are presented as total $(\mathrm{g})$ and adjusted based on final $\mathrm{BW}(\mathrm{g} / \mathrm{kg}$ of $\mathrm{BW})$. 
determined that $\mathrm{R}$-fed calves with estradiol implants exhibited greater $(P<0.05)$ ADG on wk 9 and 10 than both EH-fed treatment groups (Figure 2C). Also, R-fed calves lacking estradiol implants had a greater $(P$ $<0.05)$ ADG than EH-fed calves lacking estradiol implants. Both diet and estradiol treatment altered ADG over the entire 10-wk period (Figure 2D), with EH-fed calves provided estradiol implants displaying the greatest $(P<0.05)$ ADG and EH-fed calves not provided estradiol performing better $(P<0.05)$ than either of the R-fed groups.

\section{Reproductive Tract Metrics}

Several gross anatomical assessments of reproductive tracts were made when calves were euthanized at wk 8 and 10 (Tables 2 and 3). At 8 wk of age, weights for the entire reproductive tract, uterus, and cervix were greater $(P<0.05)$ in $\mathrm{EH}-$ than $\mathrm{R}$-fed calves. After adjusting for $\mathrm{BW}$, none of these weights differed between diets. Neither unadjusted nor BW-adjusted ovarian weights differed based on diet at 8 wk.

In the second study, both diet and estradiol treatment on wk 9 and 10 influenced reproductive tract weights (Table 3). Both unadjusted and BW-adjusted reproductive tract weights were greater $(P<0.05)$ in EH-fed calves implanted with estradiol than all other treatment groups.

Uterine weights also differed at wk 10 depending on diet and estradiol treatment (Table 3), with unadjusted uterine weights being greatest $(P<0.05)$ in $\mathrm{EH}$-fed calves provided estradiol and least $(P<0.05)$ in $\mathrm{R}$ fed calves provided a placebo. Unadjusted and BWadjusted uterine weights were less $(P<0.05)$ in $\mathrm{R}$-fed calves provided estradiol than R-fed calves lacking estradiol treatment, but the opposite effect was observed in the EH-fed calves, where EH-fed calves administered estradiol had greater $(P<0.05)$ unadjusted and BWadjusted uterine weights than EH-fed calves not provided estradiol.

At 10 wk of age, cervix weight was greatest $(P<$ $0.05)$ for estradiol-treated EH-fed calves and least $(P$ $<0.05)$ for R-fed calves with no supplemental estradiol (Table 3). Estradiol treatment increased $(P<0.05)$ BW-adjusted cervix weights in both R- and EH-fed calves. Nonadjusted ovarian weights were greater $(P$ $<0.05)$ in EH- than R-fed calves supplemented with estradiol, but no differences in ovarian weights were detected after adjusting for BW.

Assessments of follicle numbers were completed in both replicate studies. At 8 wk of age, neither total follicle numbers nor follicle numbers adjusted for ovarian weights were altered due to diet (Table 2). At $10 \mathrm{wk}$ of age, estradiol-dependent effects on follicle numbers were detected (Table 3), where total follicle numbers were greater $(P<0.05)$ in EH-fed calves supplemented with estradiol than EH-fed calves not provided estradiol. Total follicle numbers for both R-fed groups were not different $(P>0.05)$ from each other or from the $\mathrm{EH}$-fed groups; however, after adjusting for ovarian weight, both estradiol-treated $\mathrm{EH}$ - and R-fed calves contained more $(P<0.05)$ visible follicles than counterparts administered a placebo.

Table 3. Reproductive tract weights and follicle numbers of heifer calves fed either a restricted (R) or enhanced (EH) milk replacer (MR) diet with (+) or without (-) estradiol (E2) for 10 wk $( \pm$ SEM)

\begin{tabular}{|c|c|c|c|c|}
\hline \multirow[b]{2}{*}{ Parameter $^{1}$} & \multicolumn{2}{|c|}{ R-MR } & \multicolumn{2}{|c|}{ EH-MR } \\
\hline & $\begin{array}{c}-\mathrm{E} 2 \\
(\mathrm{n}=6)\end{array}$ & $\begin{array}{c}+\mathrm{E} 2 \\
(\mathrm{n}=6)\end{array}$ & $\begin{array}{c}-\mathrm{E} 2 \\
(\mathrm{n}=5)\end{array}$ & $\begin{array}{c}+\mathrm{E} 2 \\
(\mathrm{n}=6)\end{array}$ \\
\hline $\begin{array}{l}\text { Final BW (kg) } \\
\text { Reproductive tract }\end{array}$ & $61.9 \pm 1.5^{\mathrm{a}}$ & $62.7 \pm 1.8^{\mathrm{a}}$ & $73.0 \pm 5.6^{\mathrm{b}}$ & $83.1 \pm 2.3^{\mathrm{c}}$ \\
\hline $\begin{array}{l}\mathrm{g} \\
\mathrm{g} / \mathrm{kg} \text { of } \mathrm{BW}\end{array}$ & $\begin{array}{l}31.9 \pm 2.8^{\mathrm{a}} \\
0.56 \pm 0.05^{\mathrm{a}}\end{array}$ & $\begin{array}{l}27.0 \pm 1.0^{\mathrm{a}} \\
0.47 \pm 0.02^{\mathrm{ab}}\end{array}$ & $\begin{array}{l}26.9 \pm 3.6^{\mathrm{a}} \\
0.40 \pm 0.03^{\mathrm{b}}\end{array}$ & $\begin{array}{l}48.8 \pm 3.2^{\mathrm{b}} \\
0.66 \pm 0.03^{\mathrm{c}}\end{array}$ \\
\hline $\begin{array}{l}\text { Uterus } \\
\mathrm{g} \\
\mathrm{g} / \mathrm{kg} \text { of } \mathrm{BW}\end{array}$ & $\begin{array}{l}26.9 \pm 2.3^{\mathrm{a}} \\
0.47 \pm 0.04^{\mathrm{a}}\end{array}$ & $\begin{array}{l}18.5 \pm 1.0^{\mathrm{b}} \\
0.32 \pm 0.02^{\mathrm{b}}\end{array}$ & $\begin{array}{l}19.1 \pm 1.9^{\mathrm{b}} \\
0.29 \pm 0.01^{\mathrm{b}}\end{array}$ & $\begin{array}{l}34.9 \pm 1.9^{\mathrm{c}} \\
0.47 \pm 0.02^{\mathrm{a}}\end{array}$ \\
\hline $\begin{array}{l}\text { Cervix } \\
\mathrm{g} \\
\mathrm{g} / \mathrm{kg} \text { of } \mathrm{BW}\end{array}$ & $\begin{aligned} 5.0 & \pm 0.8^{\mathrm{a}} \\
0.10 & \pm 0.01^{\mathrm{a}}\end{aligned}$ & $\begin{aligned} 8.5 & \pm 0.7^{\mathrm{b}} \\
0.15 & \pm 0.01^{\mathrm{b}}\end{aligned}$ & $\begin{array}{r}7.2 \pm 1.4^{\mathrm{ab}} \\
0.11 \pm 0.01^{\mathrm{a}}\end{array}$ & $\begin{array}{l}13.7 \pm 1.8^{\mathrm{c}} \\
0.18 \pm 0.02^{\mathrm{b}}\end{array}$ \\
\hline $\begin{array}{l}\text { Ovaries } \\
\mathrm{g} \\
\mathrm{g} / \mathrm{kg} \text { of } \mathrm{BW}\end{array}$ & $\begin{aligned} 3.2 & \pm 0.4^{\mathrm{ab}} \\
0.06 & \pm 0.01^{\mathrm{a}}\end{aligned}$ & $\begin{aligned} 2.0 & \pm 0.5^{\mathrm{a}} \\
0.04 & \pm 0.01^{\mathrm{a}}\end{aligned}$ & $\begin{array}{r}2.9 \pm 0.7^{\mathrm{ab}} \\
0.04 \pm 0.01^{\mathrm{a}}\end{array}$ & $\begin{array}{r}4.5 \pm 1.2^{\mathrm{bc}} \\
0.06 \pm 0.01^{\mathrm{a}}\end{array}$ \\
\hline $\begin{array}{l}\text { Follicle numbers } \\
\text { Total } \\
\text { Number/g of tissue }\end{array}$ & $\begin{aligned} 37.2 & \pm 16.0^{\mathrm{ab}} \\
9.8 & \pm 3.0^{\mathrm{a}}\end{aligned}$ & $\begin{array}{l}50.3 \pm 15.8^{\mathrm{ab}} \\
22.9 \pm 3.8^{\mathrm{b}}\end{array}$ & $\begin{aligned} 20.2 & \pm 8.9^{\mathrm{a}} \\
6.4 & \pm 1.8^{\mathrm{a}}\end{aligned}$ & $\begin{array}{l}94.7 \pm 38.4^{\mathrm{b}} \\
16.7 \pm 3.6^{\mathrm{b}}\end{array}$ \\
\hline
\end{tabular}

${ }^{\mathrm{a} c}$ Different superscripts within row denote differences $(P<0.05)$.

${ }^{1}$ Weight data are presented as total (g) and adjusted based on final BW (g/kg of BW). 


\section{Endometrial Gland Morphometrics}

Diet affected uterine gland measurements after $8 \mathrm{wk}$ (Figure 3A-C). The EH-fed calves contained greater $(P$ $<0.05)$ numbers of uterine glands (Figure 3A) that were smaller $(P<0.05)$ in size (Figure $3 \mathrm{~B})$ than $\mathrm{R}$-fed calves. No diet-dependent difference in the percentage of total endometrial area occupied by glands was observed (Figure 3C). No diet or estradiol effects were detected at $10 \mathrm{wk}$ of age (Figure 4). No differences in uterine gland morphologies were detected between uterine horns or among sections within individuals (data not shown).

\section{Endometrial Transcript Profiles}

At 8 wk of age, EH-fed calves contained greater $(P$ $<0.05)$ mRNA transcript abundance for IGF1 and IGFBP1 (Figure 5A). The EH-fed calves also contained reduced $(P<0.05)$ amounts of WNT7A (Figure 5A). No differences in transcript abundances for ESR1, FGF10, FGFR2, FGFR2IIIb, HGF, MET, IGFBP3,

\section{A}
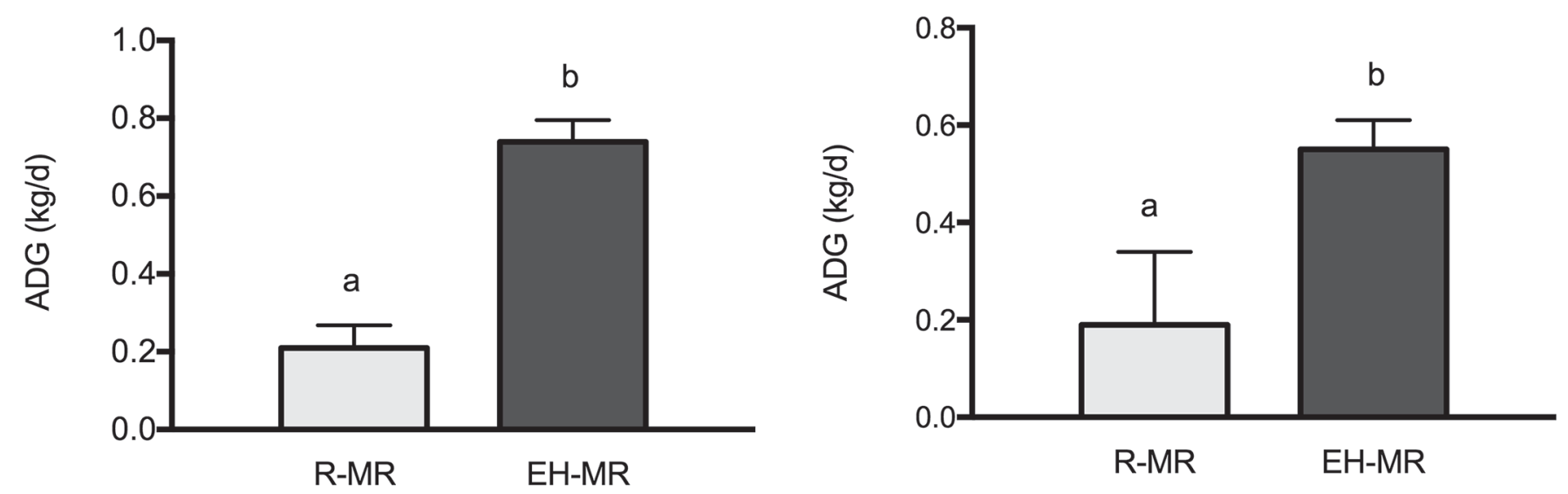

C
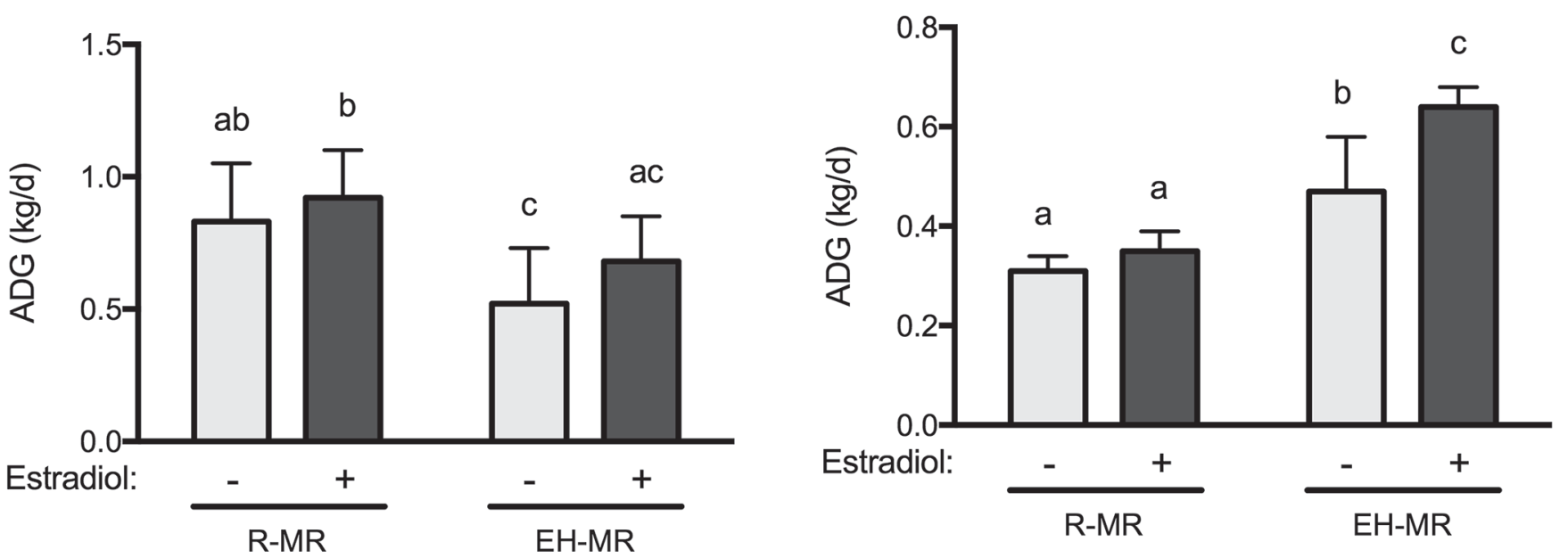

Figure 2. Average daily gain for heifer calves. Calves $(\mathrm{n}=5-6 /$ treatment) fed either a restricted $(\mathrm{R})$ or enhanced (EH) milk replacer $(\mathrm{MR})$ diet for 8 wk. In the first study, calves were euthanized at 8 wk of age. (A) The ADG of calves in study 1. In the second study, calves were exposed to estradiol or blank implants from wk 8 to 10 and then euthanized. (B) The ADG of heifers for the first 8 wk; (C) ADG between wk 8 and 10; (D) ADG for the entire 10-wk period. Different letters $(\mathrm{a}-\mathrm{c})$ within each panel denote differences $(P<0.05)$. Error bars indicate SEM. 
A

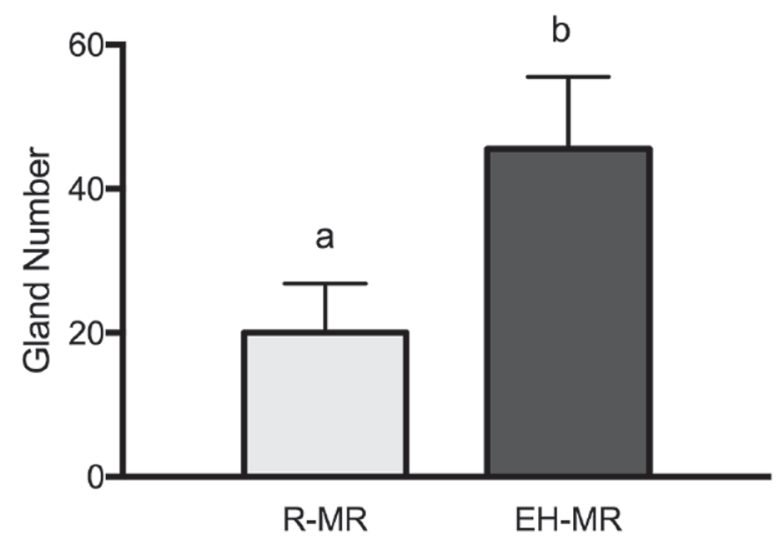

B
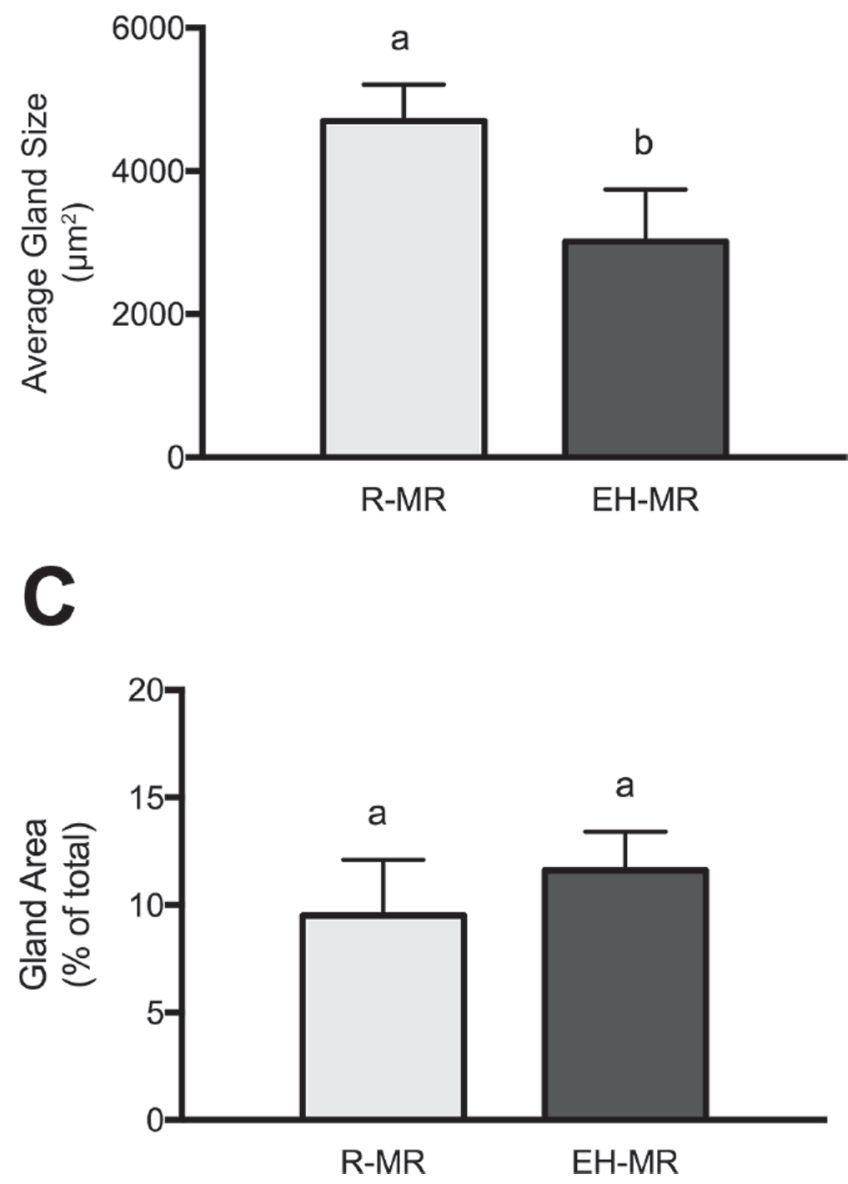

Figure 3. Morphometric analysis of endometrial glands at 8 wk of age. Calves ( $\mathrm{n}=5-6 /$ treatment) were fed either a restricted $(\mathrm{R})$ or enhanced (EH) milk replacer (MR) diet for $8 \mathrm{wk}$, and then were euthanized. Endometrial cross sections were harvested and processed for hematoxylin staining and image analysis. (A) Gland number (adjusted for total area evaluated); (B) average gland size; (C) percentage of the total endometrial area evaluated occupied by glandular epithelia and lumen. Different letters $(\mathrm{a}, \mathrm{b})$ within each panel represent differences $(P<0.05)$. Error bars indicate SEM.
A
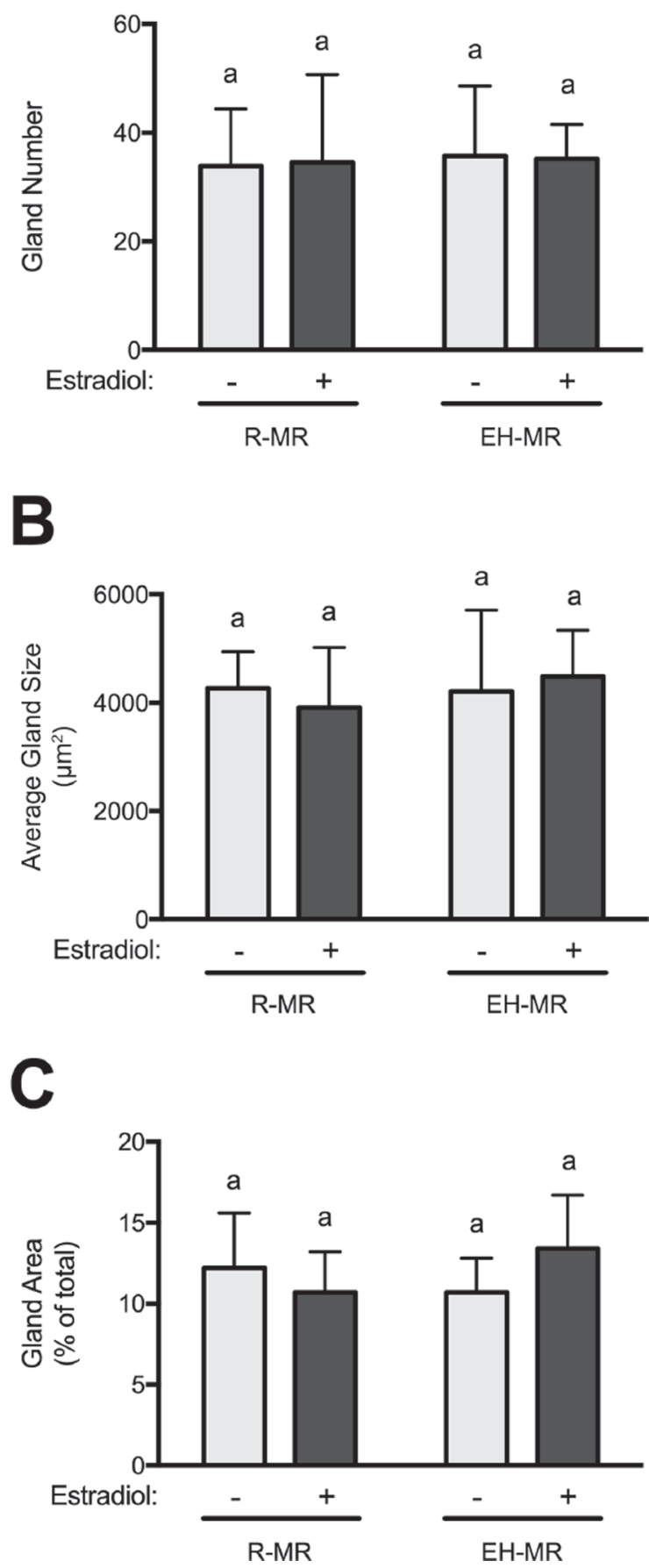

Figure 4. Morphometric analysis of endometrial glands at $10 \mathrm{wk}$ of age. Calves $(\mathrm{n}=5-6 /$ treatment) were fed either a restricted $(\mathrm{R})$ or enhanced $(\mathrm{EH})$ milk replacer $(\mathrm{MR})$ diet and then were exposed to estradiol or blank implants from wk 8 to 10 . Calves were euthanized at $10 \mathrm{wk}$ of age. Endometrial cross sections were harvested and processed for hematoxylin staining and image analysis. (A) Gland number (adjusted for total area evaluated); (B) average gland size; (C) percentage of the total endometrial area evaluated occupied by glandular epithelia and lumen. No differences between treatments within each figure were detected $(P>0.05)$, indicated by common letter $(\mathrm{a})$. Error bars indicate SEM. 
and WNT5A were detected at wk 8. Diet did not affect transcript abundance at $10 \mathrm{wk}$ of age (Figure $5 \mathrm{~B}$ ); however, $M E T$ and WNTrA mRNA abundance was reduced $(P<0.05)$ in endometria from groups not provided estrogen. No other estradiol or estradiol by diet interaction was detected.

\section{DISCUSSION}

Two milk replacers with different compositions were fed at different levels from wh 1 to 8 of life to create the R- and EH-MR diets. Similar to other studies, the 2 diets produced differences in BW and ADG (Hill et al., 2008; Daniels et al., 2009). This marked difference in growth performance was exacerbated beyond what would normally occur in a commercial setting by limitfeeding starter grain consumption in the R-fed calves to levels consumed by the EH-fed group. Grain consumption by the EH-fed group is reduced due the excessive $\mathrm{CP}$ and fat in MR (Sweeney et al., 2010; de Passillé et al., 2011; Geiger et al., 2016). Thus, the R- and EH-MR diets provided a suitable deviation in growth performance to serve as a model for examining how plane of nutrition affects postnatal reproductive tract development. The R-fed group likely does not mirror commercial calves; their growth rates were well below industry standards for growing dairy calves during milk replacer feeding (Sweeney et al., 2010; de Passillé et al., 2011; Geiger et al., 2016).

Both EH feeding and estradiol supplementation improved postweaning performance in calves. The greater ADG observed in R-fed calves after weaning is especially interesting when considering that starter grain consumption in the R-fed calves was restricted to the same level consumed by calves on the $\mathrm{EH}$ diet (via employing a pair-wise feeding strategy). This likely represents the heightened preparedness of the rumen and intestines in R-fed calves for grain consumption (Brown et al., 2005; Hill et al., 2008). Estradiol supplementation minimized the reduction in growth performance observed in EH-fed calves. Estradiol-containing implants are commonly used to improve pre- and postweaning beef heifer growth performance (Sawyer et al., 1987; Moran et al., 1991; Hardt et al., 1995; Cleale et al., 2013).

The primary goal of our work was to examine how postnatal diet and estrogen exposure affects uterine gland development. The timing of adenogenesis remains largely unexplored in early postnatal calf development. In the ewe lamb (Bartol et al., 1988b; Taylor et al., 2000), shallow luminal epithelial crypts appear in intercaruncular regions between postnatal d (PD) 0 and 7. Glandular epithelial buds invaginate into the stroma by PD14, and tubular structures with minimal branching exist by PD21. After PD21, coining and branching morphogenesis of the tubular glands occurs and the depth of the glands continues until it reaches the deep stratum spongiosum stroma. By PD56 (8 wk of age), endometrial glands are histologically similar to the adult uterus. The outcomes presented here suggest that a similar timeline exists for heifer calves, although diet affected the progression of this process.

In the present studies, dietary interventions were not initiated until $6 \pm 2$ d of age. Earlier initiation of these diets was not possible because the calves were not born on-site. Thus, uterine gland development was already underway as the dietary treatments were initiated (Bartol et al., 1988b; Taylor et al., 2000). Even so, differences in rate of uterine gland formation could be detected at 8 wk of age. Based on the outcomes, we proposed that the alterations in gland size and number at $8 \mathrm{wk}$ of age between calves on the 2 diets reflect changes in the progression of adenogenesis. The larger size and lower numbers of glands in R-fed calves strongly suggest that these calves had progressed through the initial stages of adenogenesis but contained glands that were less coiled and branched than the EH-fed calves. The size and shape of glandular structures support this contention. The lack of differences in uterine gland morphology or gland numbers and size between diets at 10 wk of age suggests that R-fed calves have the capacity to complete adenogenesis within this 2 -wk window. Alternatively, as heifers were placed on the same diets between wk 8 and 10 (weaned from MR and fed starter grain exclusively), it is possible that feeding a common diet over this short period may have influenced uterine gland status at the end of wk 10 .

The implications of the altered ontogeny of uterine development remain speculative. The compensatory gland development between 8 and 10 wk may prevent long-lasting adverse consequences on fecundity in the $\mathrm{R}$-fed calves. However, as will be discussed, endometrial gene expression was altered at 8 and 10 wk of age based on plane of nutrition; thus, long-lasting effects of early nutrition may indeed exist.

Uterine expression profiling work suggests that the local IGF1 system plays a part in mediating the progression of adenogenesis based on postnatal nutritional status. Locally derived IGF1 is an essential mesenchymal regulator of postnatal uterine gland development in mammals. In mice, uterine glands are absent in $I G F 1$ null females (Baker et al., 1996). In the sheep, IGF1 and several $I G F B P$ are expressed in the endometrial stroma, and $I G F 1$ receptor is expressed in glandular epithelium (Taylor et al., 2001). In our study, endometrial IGF1 mRNA abundance was greater in EH- than R-fed calves at $8 \mathrm{wk}$, but not $10 \mathrm{wk}$ of age. Several IGFBP also are expressed in the postnatal ovine endometrium (Hayashi et al., 2005), and in calves IGFBP1 mRNA 
A

$\square$ R-MR $\square$ EH-MR

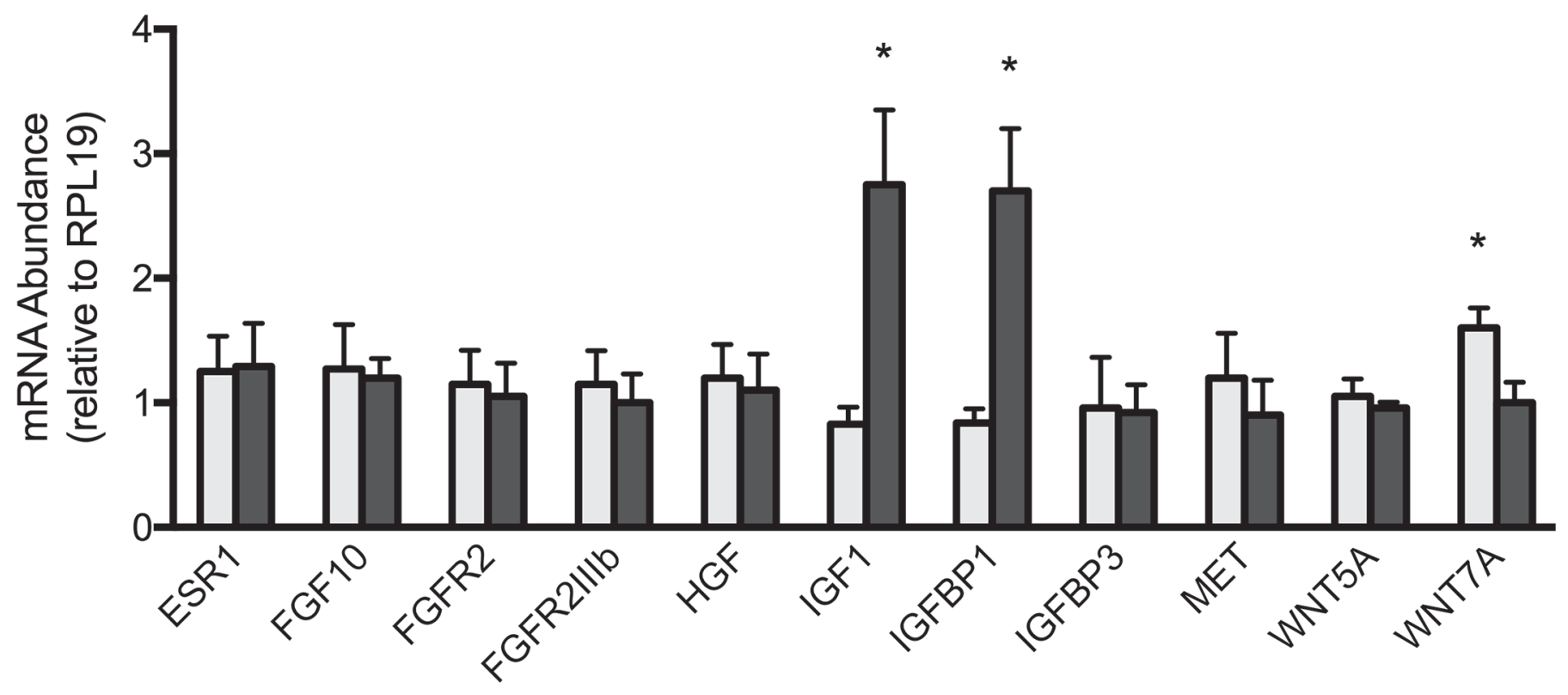

B

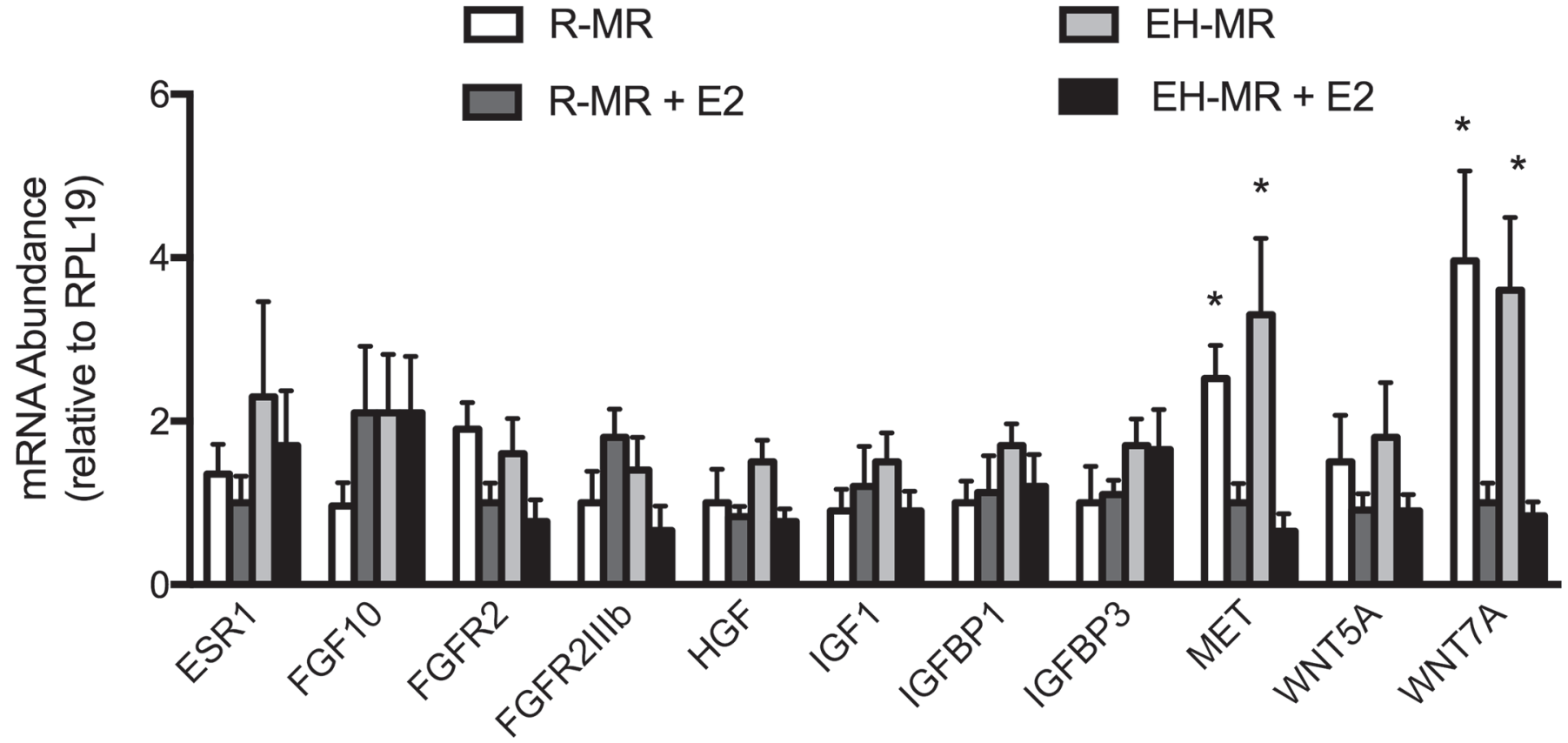

Figure 5. Selective transcript profiles for endometrial gland regulatory genes. Calves $(\mathrm{n}=5-6 /$ treatment) were fed either a restricted ( $\mathrm{R})$ or enhanced (EH) milk replacer (MR) diet. (A) Calves were euthanized at 8 wk of age and endometrial samples were collected and processed for RNA extraction and quantitative reverse-transcription PCR. (B) Calves were exposed to estradiol (E2) or blank implants from wk 8 to 10. Calves then were euthanized and endometrial samples were collected and processed. Data are depicted as transcript abundance relative to the reference control (RPL19). The asterisk $\left(^{*}\right)$ indicates differences between diet $(\mathrm{A})$ or estradiol treatment $(\mathrm{B})(P<0.05)$. Error bars indicate SEM. 
was greater in EH-fed calves at 8 wk of age whereas IGFBP3 mRNA abundance was not different between groups at either time point.

Transcript abundance for WNT5a and WNT7a was examined in the current work because each patterning factor is involved with endometrial epithelium proliferation and uterine gland formation. Gene WNT7a was of primary interest because ablation of $W N T 7 A$ gene function prevents uterine gland formation in mice (Dunlap et al., 2011). Also, steroid-induced disruption in gland formation reduces $W N T T^{r} / A$ expression in sheep (Hayashi and Spencer, 2006; Spencer et al., 2012). Ovine $W N T T^{\top} A$ is expressed solely by endometrial epithelium (Hayashi and Spencer, 2006; Hayashi et al., 2007). If the premise that endometria in R-fed calves contain less developed glands, and thus fewer glandular epithelia, then one would expect reduced endometrial WNT7A abundance. However, the opposite scenario occurred, wherein the R-fed calves contained a greater abundance of $W N T$ r $A$ mRNA than the EH-fed calves at wk 8. Perhaps the increased expression of $W N T 7 A$ reflects a compensatory mechanism for overcoming the adverse effects of reduced nutrition on uterine gland morphogenesis. The relative abundance of $W N T$ TrA was not different between dietary groups at $10 \mathrm{wk}$ of age, when uterine gland development in the R-fed calves had reached the same developmental status as those found in the EH-fed calves.

The remaining paracrine and endocrine regulators of endometrial adenogenesis examined herein were not affected by diet at wk 8 or 10 . Of particular interest was examining FGF10 and HGF; these stroma-derived factors interact with their luminal and glandular epitheliallocalized receptors (FGFR2IIIb and MET, respectively) expressed throughout early postnatal life (Chen et al., 2000a,b; Satterfield et al., 2008). Their key morphogenetic roles in other epithelial tissues, such as lung and intestinal epithelium, implicate them as mediators of similar activities in the uterus (Sekine et al., 1999; Shin et al., 2006). Expression of ESR1, although unchanged, was examined based on its importance for normal gland branching and coiling in ewes (Carpenter et al., 2003a). Efforts also were made to examine PRLR abundance. Prolactin is needed for normal early gland development and glandular epithelial proliferation in sheep (Taylor et al., 2000; Carpenter et al., 2003b). Both the long and short PRLR isoforms have been detected in ovine glandular epithelium, with greatest concentrations of each within proliferating glandular regions (Taylor et al., 2000). Previously validated bovine $P R L R$ primers (Tao et al., 2013) failed to detect either isoform.

Another goal of this work was to examine how estradiol exposure affects uterine gland development and gene expression. Similar amounts of estradiol were provided in this work that were provided in previous studies in ewe lambs (Hayashi et al., 2004), although studies in sheep provided daily estradiol injections whereas implants were used for the present work. The lack of estradiol effects on adenogenesis likely occurred because the estradiol treatment did not begin until wk 9. Inhibitory effects of estradiol are more readily apparent during the initial periods of adenogenesis (Hayashi et al., 2004). The estradiol implant decreased MET and $W N T$ r $A$ expression in both dietary groups; both factors are estrogen-sensitive (Hayashi and Spencer, 2005, 2006). In previous work, the most severe reduction in uterine gland development in beef heifers was observed when progesterone and estradiol implants were provided at birth, but reductions in uterine gland development were also detected when implants were provided at 21 or $45 \mathrm{~d}$ of age (Bartol et al., 1995). In Bartol et al. (1995), implanted heifers contained lower uterine luminal proteins than nonimplanted controls regardless of when the implants were first administered.

Additional endpoint analyses were made to explore how diet and estrogen supplementation affects gross reproductive tract anatomy. In the present studies, changes in uterine weight were the primary determinant of the observed changes in overall reproductive tract weight. For the calves not supplemented with estradiol, it is unclear why EH-fed calves had lighter uteri than R-fed calves; perhaps this outcome occurred because of the poor postweaning performance of this group. Uterine weights were improved in EH-fed calves supplemented with estradiol, which is consistent with the expected uterotrophic effects of estrogen supplementation observed in multiple species, including cattle (Prichard et al., 1989; Burton and Wells, 2002). However, estradiol supplementation suppressed uterine weights in the R-fed calves, which suggests that nutritional status interferes with the positive effects of estradiol on the uterus.

Weight of the cervix was not affected by diet at wk 10, but both dietary groups possessed the same estradiol-dependent increase in cervix weight. It is not clear if the increases in cervical weight represent a positive influence of estradiol on cervix development or if it indicates the beginning of cervical malformations that may reduce fertility. In sheep, long-term exposure to estradiol compromises cervical morphology and specifically increases the incidence of cervical fold fusion and glandular cyst formation and reduces mucus cell numbers (Adams, 1995b). Changes in mucus composition following estrogen exposure are implicated for reducing sperm transport and subsequent fertilization rates (Adams, 1995a,b).

Estradiol-dependent ovarian responses were evident in the calves examined at $10 \mathrm{wk}$ of age. Visible follicle 
numbers were increased in both estradiol-treated EHand R-fed calves; it is uncertain whether this is a positive or negative outcome. Follicle numbers of calves are directly related to subsequent ovarian function and fertility (Ireland et al., 2011; Mossa et al., 2013); however, general consensus is that growth-promoting implants containing estradiol can have detrimental effects on fertility when administered to heifers (Deutscher et al., 1986; Bartol et al., 1995; Lamb, 2013). The ovary is one likely target for these negative consequences. Providing an estradiol agonist at 1, 6, or 9 mo of age increased the incidence of ovarian cysts and estrus activity not associated with ovulation in heifers (Deutscher et al., 1986). Neither BW-adjusted ovarian weights nor follicle numbers were altered by calf diet. Failure to detect changes in follicle numbers may have been due to the short duration on the diet or conducting follicle counts too soon after beginning estradiol treatment. Visible follicle numbers are an indicator of ovarian follicle reserve status in cattle (Ireland et al., 2009), and links between gestational nutrition and ovarian follicle reserve status are evident in sheep and cattle (Evans et al., 2012; Viñoles et al., 2013). However, no evidence exists to indicate that visible follicle numbers or the underlying ovarian follicle reserve can be adversely affected in the early postnatal period; no such detrimental effects could be detected in this work.

\section{CONCLUSIONS}

The timeline of adenogenesis in calves appears similar to that of sheep, where most branching morphogenesis occurs by 8 wk of age. However, restricted feeding appears to delay the normal progression of adenogenesis, as seen by the reduction in gland cross-section numbers and uterine wet weights at 8 wk of age. These dietdependent delays in uterine development are corrected 2 wk after weaning. The work also provides additional evidence that early postnatal exposure to estradiol negatively affects reproductive tract development. No detectable alterations in uterine histoarchitecture were evident when estradiol treatment was provided near the completion of adenogenesis; however, a subset of local adenogenesis regulators was altered by estradiol treatment and visible follicle numbers were excessively great in these calves. These observations support the contention that early estradiol exposure is detrimental to uterine activity, ovarian activity, and fertility in adults. To conclude, early plane of nutrition may dictate the rate of uterine gland development in cattle, and early estradiol exposure has detrimental effects on uterine gene expression and ovarian physiology.

\section{ACKNOWLEDGMENTS}

We thank Catherine Parsons, Jennifer Bradley, and Emily Horton for technical assistance. We also thank the managers and staff at the Virginia Tech Dairy Center for their assistance with the animal portion of this work. We acknowledge Land O' Lakes Inc. (St. Paul, $\mathrm{MN}$ ) for donating milk replacer. We also acknowledge grant support from the USDA Agricultural and Food Research Initiative (AFRI) competitive grants program, no. 2016-67015-24565 "Impact of Pre-weaning Nutrition on Endocrine Induction of Mammary Development in Dairy Heifers" awarded to R. M. Akers, USDA award no. 2011-67195-30688 "Developmental programming during Preimplantation development" awarded to A. D. Ealy (co-investigator), and USDA award no. 201667011-24703, a pre-doctoral fellowship awarded to A. J. Geiger from the USDA-Food, Agriculture, Natural Resources and Human Sciences Education and Literacy Initiative competitive grants program.

\section{REFERENCES}

Adams, N. R. 1995a. Detection of the effects of phytoestrogens on sheep and cattle. J. Anim. Sci. 73:1509-1515.

Adams, N. R. 1995b. Organizational and activational effects of phytoestrogens on the reproductive tract of the ewe. Proc. Soc. Exp. Biol. Med. 208:87-91.

Baker, J., M. P. Hardy, J. Zhou, C. Bondy, F. Lupu, A. R. Bellve, and A. Efstratiadis. 1996. Effects of an Igf1 gene null mutation on mouse reproduction. Mol. Endocrinol. 10:903-918.

Bartol, F. F., L. L. Johnson, J. G. Floyd, A. A. Wiley, T. E. Spencer, D. F. Buxton, and D. A. Coleman. 1995. Neonatal exposure to progesterone and estradiol alters uterine morphology and luminal protein content in adult beef heifers. Theriogenology 43:835-844.

Bartol, F. F., A. A. Wiley, D. A. Coleman, D. F. Wolfe, and M. G. Riddell. 1988a. Ovine uterine morphogenesis: Effects of age and progestin administration and withdrawal on neonatal endometrial development and DNA synthesis. J. Anim. Sci. 66:3000-3009.

Bartol, F. F., A. A. Wiley, J. G. Floyd, T. L. Ott, F. W. Bazer, C. A. Gray, and T. E. Spencer. 1999. Uterine differentiation as a foundation for subsequent fertility. J. Reprod. Fertil. Suppl. 54:287-302.

Bartol, F. F., A. A. Wiley, and D. R. Goodlett. 1988b. Ovine uterine morphogenesis: histochemical aspects of endometrial development in the fetus and neonate. J. Anim. Sci. 66:1303-1313.

Becker, C., I. Riedmaier, M. Reiter, A. Tichopad, M. J. Groot, A. A. Stolker, M. W. Pfaffl, M. F. Nielen, and H. H. Meyer. 2011. Influence of anabolic combinations of an androgen plus an estrogen on biochemical pathways in bovine uterine endometrium and ovary. J. Steroid Biochem. Mol. Biol. 125:192-201.

Brown, E. G., M. J. Vandehaar, K. M. Daniels, J. S. Liesman, L. T. Chapin, J. W. Forrest, R. M. Akers, R. E. Pearson, and M. S. Nielsen. 2005. Effect of increasing energy and protein intake on mammary development in heifer calves. J. Dairy Sci. 88:595-603.

Burton, J. L., and M. Wells. 2002. The effect of phytoestrogens on the female genital tract. J. Clin. Pathol. 55:401-407.

Carpenter, K. D., C. A. Gray, T. M. Bryan, T. H. Welsh Jr., and T. E. Spencer. 2003a. Estrogen and antiestrogen effects on neonatal ovine uterine development. Biol. Reprod. 69:708-717.

Carpenter, K. D., C. A. Gray, S. Noel, A. Gertler, F. W. Bazer, and T. E. Spencer. 2003b. Prolactin regulation of neonatal ovine uterine gland morphogenesis. Endocrinology 144:110-120. 
Chen, C., T. E. Spencer, and F. W. Bazer. 2000a. Expression of hepatocyte growth factor and its receptor c-met in the ovine uterus. Biol. Reprod. 62:1844-1850.

Chen, C., T. E. Spencer, and F. W. Bazer. 2000b. Fibroblast growth factor-10: A stromal mediator of epithelial function in the ovine uterus. Biol. Reprod. 63:959-966.

Cleale, R. M., D. Amodie, D. T. Bechtol, J. S. Drouillard, J. D. Edmonds, M. Edmonds, B. D. Hunsaker, L. A. Kraft, T. E. Lawrence, R. D. Rulli, and A. R. Waite. 2013. Effects of estradiol benzoate and trenbolone acetate, alone or in combination at dose levels present in Synovex Choice, on performance by feedlot heifers. J. Anim. Sci. 91:970-977.

Cooke, F. N., K. A. Pennington, Q. Yang, and A. D. Ealy. 2009. Several fibroblast growth factors are expressed during pre-attachment bovine conceptus development and regulate interferon-tau expression from trophectoderm. Reproduction 137:259-269.

Daniels, K. M., A. V. Capuco, M. L. McGilliard, R. E. James, and R. M. Akers. 2009. Effects of milk replacer formulation on measures of mammary growth and composition in Holstein heifers. J. Dairy Sci. 92:5937-5950.

Davis Rincker, L. E., M. J. Vandehaar, C. A. Wolf, J. S. Liesman, L. T. Chapin, and M. S. Weber Nielsen. 2011. Effect of intensified feeding of heifer calves on growth, pubertal age, calving age, milk yield, and economics. J. Dairy Sci. 94:3554-3567.

de Passillé, A. M., T. F. Borderas, and J. Rushen. 2011. Weaning age of calves fed a high milk allowance by automated feeders: effects on feed, water, and energy intake, behavioral signs of hunger, and weight gains. J. Dairy Sci. 94:1401-1408.

Deutscher, G. H., L. L. Zerfoss, and D. C. Clanton. 1986. Time of zeranol implantation on growth, reproduction and calving of beef heifers. J. Anim. Sci. 62:875-886.

Dunlap, K. A., J. Filant, K. Hayashi, E. B. Rucker 3rd, G. Song, J. M. Deng, R. R. Behringer, F. J. DeMayo, J. Lydon, J. W. Jeong, and T. E. Spencer. 2011. Postnatal deletion of Wnt7a inhibits uterine gland morphogenesis and compromises adult fertility in mice. Biol. Reprod. 85:386-396.

Evans, A. C., F. Mossa, S. W. Walsh, D. Scheetz, F. Jimenez-Krassel, J. L. Ireland, G. W. Smith, and J. J. Ireland. 2012. Effects of maternal environment during gestation on ovarian folliculogenesis and consequences for fertility in bovine offspring. Reprod. Domest. Anim. 47(Suppl 4):31-37.

Geiger, A. J., C. L. Parsons, R. E. James, and R. M. Akers. 2016. Growth, intake, and health of Holstein heifer calves fed an enhanced preweaning diet with or without postweaning exogenous estrogen. J. Dairy Sci. 99:3995-4004.

Gray, C. A., F. F. Bartol, B. J. Tarleton, A. A. Wiley, G. A. Johnson, F. W. Bazer, and T. E. Spencer. 2001a. Developmental biology of uterine glands. Biol. Reprod. 65:1311-1323.

Gray, C. A., K. M. Taylor, W. S. Ramsey, J. R. Hill, F. W. Bazer, F. F. Bartol, and T. E. Spencer. 2001b. Endometrial glands are required for preimplantation conceptus elongation and survival. Biol. Reprod. 64:1608-1613

Hardt, P. F., L. W. Greene, and D. K. Lunt. 1995. Alterations in metacarpal characteristics in steers and heifers sequentially implanted with Synovex from 45 days of birth. J. Anim. Sci. 73:55-62.

Hayashi, K., R. C. Burghardt, F. W. Bazer, and T. E. Spencer. 2007. WNTs in the ovine uterus: Potential regulation of periimplantation ovine conceptus development. Endocrinology 148:3496-3506.

Hayashi, K., K. D. Carpenter, and T. E. Spencer. 2004. Neonatal estrogen exposure disrupts uterine development in the postnatal sheep. Endocrinology 145:3247-3257.

Hayashi, K., K. D. Carpenter, T. H. Welsh Jr., R. C. Burghardt, L. J. Spicer, and T. E. Spencer. 2005. The IGF system in the neonatal ovine uterus. Reproduction 129:337-347.

Hayashi, K., and T. E. Spencer. 2005. Estrogen disruption of neonatal ovine uterine development: effects on gene expression assessed by suppression subtraction hybridization. Biol. Reprod. 73:752-760.

Hayashi, K., and T. E. Spencer. 2006. WNT pathways in the neonatal ovine uterus: potential specification of endometrial gland morphogenesis by SFRP2. Biol. Reprod. 74:721-733.
Hill, S. R., K. F. Knowlton, K. M. Daniels, R. E. James, R. E. Pearson, A. V. Capuco, and R. M. Akers. 2008. Effects of milk replacer composition on growth, body composition, and nutrient excretion in preweaned Holstein heifers. J. Dairy Sci. 91:3145-3155.

Ireland, J. J., G. W. Smith, D. Scheetz, F. Jimenez-Krassel, J. K. Folger, J. L. Ireland, F. Mossa, P. Lonergan, and A. C. Evans. 2011. Does size matter in females? An overview of the impact of the high variation in the ovarian reserve on ovarian function and fertility, utility of anti-Mullerian hormone as a diagnostic marker for fertility and causes of variation in the ovarian reserve in cattle. Reprod. Fertil. Dev. 23:1-14.

Ireland, J. J., A. E. Zielak-Steciwko, F. Jimenez-Krassel, J. Folger, A. Bettegowda, D. Scheetz, S. Walsh, F. Mossa, P. G. Knight, G. W. Smith, P. Lonergan, and A. C. Evans. 2009. Variation in the ovarian reserve is linked to alterations in intrafollicular estradiol production and ovarian biomarkers of follicular differentiation and oocyte quality in cattle. Biol. Reprod. 80:954-964.

Lamb, G. C. 2013. Criteria for selecting replacements at weaning, before breeding, and after breeding. Vet. Clin. North Am. Food Anim. Pract. 29:567-578.

Lammers, B. P., A. J. Heinrichs, and R. S. Kensinger. 1999. The effects of accelerated growth rates and estrogen implants in prepubertal Holstein heifers on estimates of mammary development and subsequent reproduction and milk production. J. Dairy Sci. $82: 1753-1764$.

McCarthy, S. D., J. F. Roche, and N. Forde. 2012. Temporal changes in endometrial gene expression and protein localization of members of the IGF family in cattle: Effects of progesterone and pregnancy. Physiol. Genomics 44:130-140.

Moran, C., J. F. Quirke, D. J. Prendiville, S. Bourke, and J. F. Roche. 1991. The effect of estradiol, trenbolone acetate, or zeranol on growth rate, mammary development, carcass traits, and plasma estradiol concentrations of beef heifers. J. Anim. Sci. 69:4249-4258.

Moriel, P., S. E. Johnson, J. M. Vendramini, V. R. Mercadante, M. J. Hersom, and J. D. Arthington. 2014. Effects of calf weaning age and subsequent management system on growth and reproductive performance of beef heifers. J. Anim. Sci. 92:3096-3107.

Mossa, F., F. Carter, S. W. Walsh, D. A. Kenny, G. W. Smith, J. L. Ireland, T. B. Hildebrandt, P. Lonergan, J. J. Ireland, and A. C. Evans. 2013. Maternal undernutrition in cows impairs ovarian and cardiovascular systems in their offspring. Biol. Reprod. 88:92.

Ocón-Grove, O. M., F. N. Cooke, I. M. Alvarez, S. E. Johnson, T. L. Ott, and A. D. Ealy. 2008. Ovine endometrial expression of fibroblast growth factor (FGF) 2 and conceptus expression of FGF receptors during early pregnancy. Domest. Anim. Endocrinol. $34: 135-145$.

Ozawa, M., Q. E. Yang, and A. D. Ealy. 2013. The expression of fibroblast growth factor receptors during early bovine conceptus development and pharmacological analysis of their actions on trophoblast growth in vitro. Reproduction 145:191-201.

Prichard, D. L., T. T. Marshall, D. D. Hargrove, and T. A. Olson. 1989. Effects of creep feeding, zeranol implants and breed type on beef production: II. Reproductive development and fat deposition in heifers. J. Anim. Sci. 67:617-623.

Satterfield, M. C., K. Hayashi, G. Song, S. G. Black, F. W. Bazer, and T. E. Spencer. 2008. Progesterone regulates FGF10, MET, IGFBP1, and IGFBP3 in the endometrium of the ovine uterus. Biol. Reprod. 79:1226-1236.

Sawyer, G. J., R. H. Casey, and D. J. Barker. 1987. Growth response of steer calves treated with zeranol, oestradiol 17 beta or progesterone-oestradiol benzoate implants before and after weaning. Aust. Vet. J. 64:371-374.

Sekine, K., H. Ohuchi, M. Fujiwara, M. Yamasaki, T. Yoshizawa, T. Sato, N. Yagishita, D. Matsui, Y. Koga, N. Itoh, and S. Kato. 1999. Fgf10 is essential for limb and lung formation. Nat. Genet. $21: 138-141$.

Shin, M., S. Noji, A. Neubuser, and S. Yasugi. 2006. FGF10 is required for cell proliferation and gland formation in the stomach epithelium of the chicken embryo. Dev. Biol. 294:11-23.

Soberon, F., and M. E. Van Amburgh. 2013. Lactation biology symposium: The effect of nutrient intake from milk or milk replacer of 
preweaned dairy calves on lactation milk yield as adults: a metaanalysis of current data. J. Anim. Sci. 91:706-712.

Spencer, T. E. 2014. Biological roles of uterine glands in pregnancy. Semin. Reprod. Med. 32:346-357.

Spencer, T. E., K. A. Dunlap, and J. Filant. 2012. Comparative developmental biology of the uterus: insights into mechanisms and developmental disruption. Mol. Cell. Endocrinol. 354:34-53.

Spencer, T. E., A. A. Wiley, and F. F. Bartol. 1993. Neonatal age and period of estrogen exposure affect porcine uterine growth, morphogenesis, and protein synthesis. Biol. Reprod. 48:741-751.

Sweeney, B. C., J. Rushen, D. M. Weary, and A. M. de Passille. 2010 Duration of weaning, starter intake, and weight gain of dairy calves fed large amounts of milk. J. Dairy Sci. 93:148-152.

Tao, S., E. E. Connor, J. W. Bubolz, I. M. Thompson, B. C. do Amaral, M. J. Hayen, and G. E. Dahl. 2013. Short communication: Effect of heat stress during the dry period on gene expression in mammary tissue and peripheral blood mononuclear cells. J. Dairy Sci. 96:378-383.

Taylor, K. M., C. Chen, C. A. Gray, F. W. Bazer, and T. E. Spencer. 2001. Expression of messenger ribonucleic acids for fibroblast growth factors 7 and 10, hepatocyte growth factor, and insulin-like growth factors and their receptors in the neonatal ovine uterus. Biol. Reprod. 64:1236-1246.
Taylor, K. M., C. A. Gray, M. M. Joyce, M. D. Stewart, F. W. Bazer, and T. E. Spencer. 2000. Neonatal ovine uterine development involves alterations in expression of receptors for estrogen, progesterone, and prolactin. Biol. Reprod. 63:1192-1204.

Viñoles, C., B. L. Paganoni, K. P. McNatty, D. A. Heath, A. N. Thompson, K. M. Glover, J. T. Milton, and G. B. Martin. 2013. Follicle development, endocrine profiles and ovulation rate in adult Merino ewes: Effects of early nutrition (pre- and post-natal) and supplementation with lupin grain. Reproduction 147:101-110.

Waters, S. M., G. S. Coyne, D. A. Kenny, and D. G. Morris. 2014 Effect of dietary n-3 polyunsaturated fatty acids on transcription factor regulation in the bovine endometrium. Mol. Biol. Rep. 41:2745-2755.

Wathes, D. C., Z. Cheng, M. A. Fenwick, R. Fitzpatrick, and J. Patton. 2011. Influence of energy balance on the somatotrophic axis and matrix metalloproteinase expression in the endometrium of the postpartum dairy cow. Reproduction 141:269-281.

Yang, Q. E., S. E. Johnson, and A. D. Ealy. 2011. Protein kinase C delta mediates fibroblast growth factor-2-induced interferon-tau expression in bovine trophoblast. Biol. Reprod. 84:933-943. 